\title{
OCENA ROZWOJU SPOŁECZNO-GOSPODARCZEGO POWIATÓW WOJEWÓDZTWA PODLASKIEGO Z ZASTOSOWANIEM METOD TOPSIS ORAZ HELLWIGA²
}

\begin{abstract}
Streszczenie
Artykuł prezentuje wielowymiarową analizę porównawczą rozwoju społeczno-gospodarczego powiatów województwa podlaskiego w latach 2006 i 2013. Ocena sytuacji powiatów została przeprowadzona w czterech wyróżnionych obszarach, takich jak: demografia, podmioty gospodarcze i rynek pracy, gospodarka oraz warunki społeczne. Objęła ona analizę wskaźnikową obszarów tematycznych oraz konstrukcję rankingów powiatów z wykorzystaniem dwóch metod, tj.: metody wzorcowej Hellwiga oraz metody TOPSIS. Przedstawiono także dynamikę rozwoju powiatów w roku 2013 w stosunku do roku 2006, jak również dokonano porównania metod pod kątem występowania różnic w rankingach.
\end{abstract}

Słowa kluczowe: rozwój społeczno-gospodarczy, metody wielokryterialne, metoda TOPSIS, metoda Hellwiga, ranking powiatów

\section{EVALUATION OF SOCIO-ECONOMIC DEVELOPMENT OF PODLASKIE VOIVODESHIP COUNTIES BY MEANS OF TOPSIS AND HELLWIG'S METHODS}

\section{Summary}

The aim of this paper is to conduct a multidimensional analysis of the socio-economic development of the counties of Podlaskie Voivodeship in 2006 and 2013. The level of the counties' development was measured in four selected dimensions: demographics, business entities and job market, economy, and social conditions. These areas were investigated using the indicator-based analysis and the construction of the counties' rankings created by means of two methods: Hellwig's development pattern and TOPSIS. The author compares the circumstances of the development between 2006 and 2013. Finally, the effectiveness of the methods was evaluated based on the differences between the rankings.

Key words: socio-economic development, multi-criteria methods, TOPSIS, Hellwig's method, counties' ranking

\footnotetext{
1 Dr Dorota Sokołowska - Państwowa Wyższa Szkoła Zawodowa w Suwałkach; e-mail: dorotasokolowska@gazeta.pl; dr Marzena Filipowicz-Chomko - Wydział Informatyki, Politechnika Białostocka; e-mail: m.filipowicz@_pb.edu.pl.

2 Praca wykonana w ramach realizacji pracy statutowej S/WI/1/14.
} 


\section{Wstęp}

W literaturze przedmiotu rozwój społeczno-gospodarczy doczekał się wielu definicji i modeli [np.: Grosse, 2002, s. 25-46; Piontek, 2010, s. 117-124; Ziemiańczyk, 2010, s. 31-40; Warzecka, 2013, s. 41-55; Szirmai, 2015; Jaffee, 1998; UNDP, 1990 s. 10]. Najczęściej występujące określenia dotyczą pozytywnych zmianach zarówno ilościowych, jak i jakościowych w sferze gospodarczej (produkcja, zatrudnienie, inwestycje) oraz w sferze społecznej (wzrost poziomu czy też jakości życia).

Odzwierciedleniem zmian gospodarczych jest m.in. wartość Produktu Krajowego Brutto [Kubiczek, 2014]. Porównanie danych z 2012 roku (wykres 1.) pokazuje, że na tle kraju województwo podlaskie uplasowało się na odległej, 14. pozycji ze wskaźnikiem PKB wynoszącym 30055 zł na 1 mieszkańca, co jest wartością znacząco niższą niż średnia wartość dla kraju (PKB = 41934 zł na 1 mieszkańca).

WYKRES 1.

Wartość wskaźnika PKB w PLN na 1 mieszkańca w roku 2012 w podziale na województwa

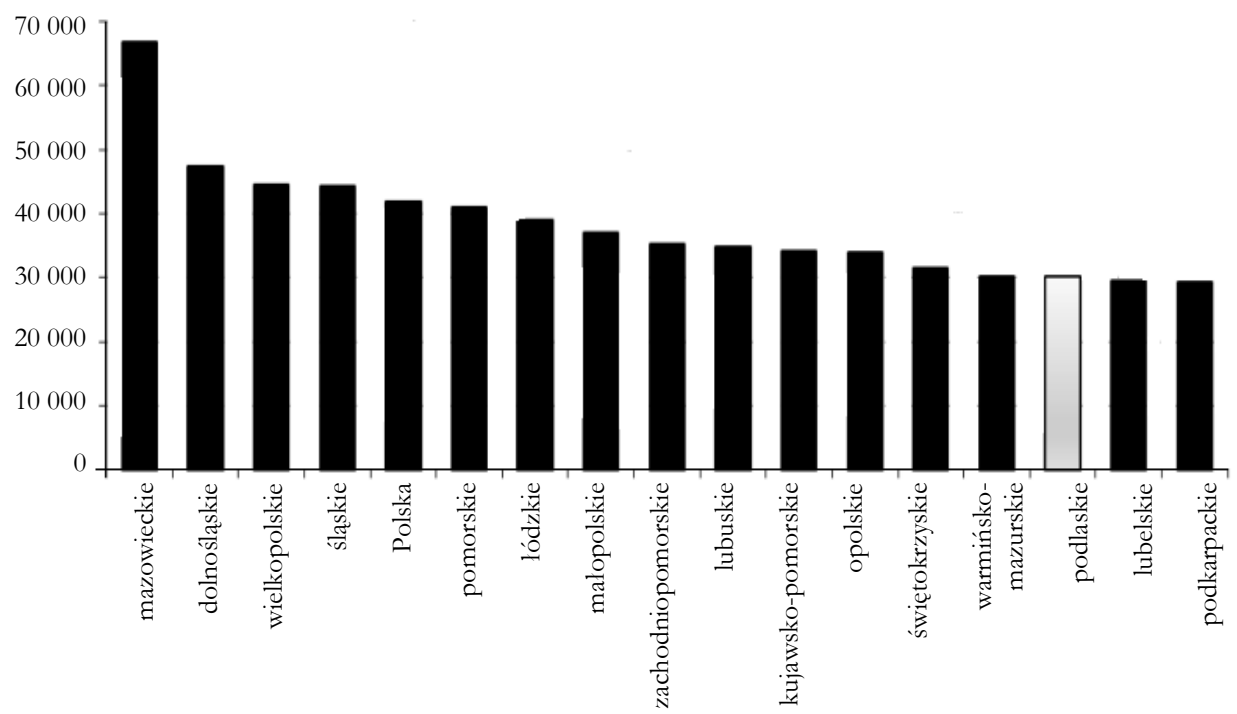

Źródło: opracowanie własne na podstawie danych z BDL z 2012 roku, dokument elektroniczny, tryb dostępu: [http://stat.gov.pl/bdl/app/dane_podgrup.display?p_id=960418\&p_ token $=0.30297774099744856$, data wejścia: 23.07.2015].

Dane przedstawione na wykresie 1. obrazują to, że w województwie podlaskim istnieje duża potrzeba poprawienia sytuacji, a przez to przyspieszenia rozwoju zarówno gospodarczego, jak i społecznego. W tym kontekście konieczna jest wielowymiarowa analiza powiatów województwa podlaskiego pod kątem rozwoju społeczno-gospodarczego. Ocena tempa rozwoju powiatów pozwoli na wyłonienie wzorcowych obszarów, które mogą służyć za przykład zmian słabszym powiatom. 
Miarą określająca poziom rozwoju społecznego jest wskaźnik LHDI ${ }^{3}$ (Lokalny Wskaźnik Rozwoju Społecznego), na który składają się: wskaźnik zdrowia HI, wskaźnik edukacji EI oraz wskaźnik zamożności WI [UNDP, 2012]. Z Krajowego Raportu o Roz̨woju Spotecznym ${ }^{4}$ [UNDP, 2012 s. 14] wynika, że województwo podlaskie znalazło się na 8. miejscu w Polsce (wykres 2.).

WYKRES 2.

Wartość wskaźnika LHDI w roku 2010, w podziale na województwa

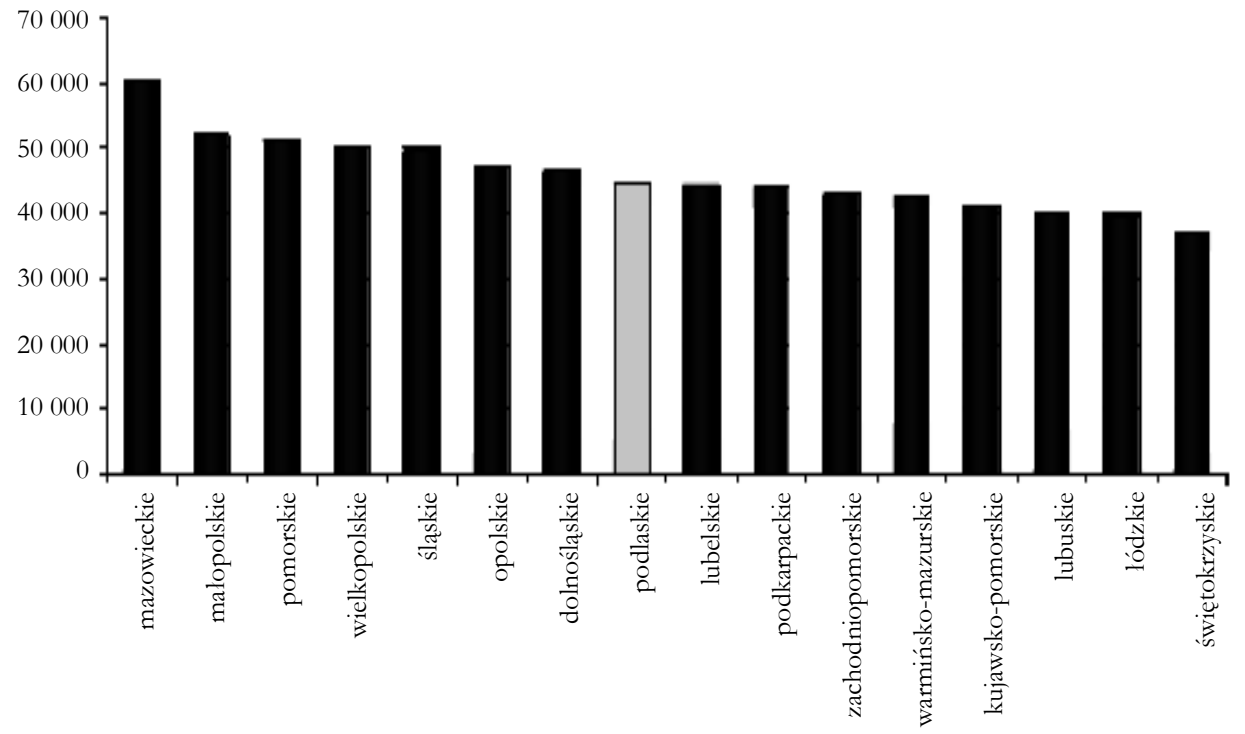

Źródło: opracowanie własne na podstawie danych: [UNDP, 2012; http://www.ewaluacja.gov.pl/ Dokumenty_ewaluacyjne/Documents/raport_undp_2012_lhdi_20420123.pdf].

Zgodnie z danymi przedstawionymi w roku 2010 [UNDP, 2012], wśród ówcześnie istniejących 379 powiatów w Polsce, w rankingu pierwszych trzydziestu najwyżej notowanych pod względem LHDI powiatów znajdował się Białystok (miasto na prawach powiatu) - miejsce 13. Natomiast końcowe pozycje tego rankingu należały aż do czterech powiatów z województwa podlaskiego, takich jak: powiat moniecki (369), powiat kolneński (374), powiat łomżyński (376) oraz ostatni w rankingu, powiat suwalski (379).

Celem opracowania jest ocena rozwoju społeczno-gospodarczego powiatów w województwie podlaskim na podstawie analizy wskaźnikowej obszarów tematycznych oraz konstrukcji rankingów tych powiatów. Zobrazowaniu dynamiki zmian posłużyła analiza wykonana dla dwóch lat: 2006 i 2013 roku. Oceną zostały objęte cztery obszary, takie jak: demografia, podmioty gospodarcze i rynek pracy, gospodarka oraz warunki społeczne.

\footnotetext{
${ }^{3} \mathrm{~W}$ wersji anglojęzycznej to Local Human Development Index.

${ }^{4}$ Dane te pochodzą z 2010 roku.
} 
Spośród metod wielokryterialnych, stosowanych do budowania rankingów, zostały wybrane dwie, tj. metoda wielokryterialnego podejmowania decyzji TOPSIS [Hwang, Yoon, 1981] oraz metoda wzorca rozwoju Hellwiga [Hellwig, 1968].

W opracowaniu wykorzystano dane Banku Danych Lokalnych Głównego Urzędu Statystycznego na poziomie NTS 4 (dane dla powiatów).

\section{Metodologia badań}

Wielowymiarowa analiza porównawcza rozwoju społeczno-gospodarczego dotyczyła 17 powiatów województwa podlaskiego i została dokonana na podstawie zbioru wskaźników charakteryzujących strefę społeczną oraz gospodarczą, wśród których wyodrębniono cztery, poniżej przedstawione obszary.

\section{Obszar I - Demografia \\ Obszar II - Podmioty gospodarcze i rynek pracy \\ Obszar III - Gospodarka \\ Obszar IV - Warunki społeczne}

Punktem wyjścia umożliwiającym ocenę oraz porównanie rozwoju społeczno-gospodarczego był dobór wskaźników ekonomicznych ogólnie opisujących tzw. ład społeczny i ład gospodarczy w tym samym zakresie czasowym [Roszkowska, Karwowska, 2014; Wskaaźniki..., 2011]. Pod uwagę wzięto dwa lata: 2006 jako pierwszy, kompletny (ze względu na dane statystyczne) rok po wejściu Polski do Unii Europejskiej oraz 20135.

Na podstawie dostępnych danych zaproponowano zbiór 40 potencjalnych zmiennych diagnostycznych (wskaźników) opisujących rozwój społeczno-gospodarczy z podziałem na cztery obszary. Dobór wskaźników był przeprowadzony według określonych kryteriów formalnych i merytorycznych. $Z$ punktu widzenia prowadzonych badań zmienne ujęte do analizy posiadały własności, takie jak: uniwersalność (wskaźniki mają uznane powszechnie znaczenie), porównywalność, słabe skorelowanie zmiennych ze sobą (pozwalające uniknać powielania informacji) oraz odpowiednie zróżnicowanie. Na pierwszym etapie analizy dokonano eliminacji wskaźników, dla których współczynnik zmienności $V$ w obu badanych latach nie przekraczał $10 \%$. W celu dalszej redukcji zmiennych zbudowano macierze korelacji między wszystkimi wskaźnikami pogrupowanymi w obszarach oraz macierze do nich odwrotne. Dokonując analizy elementów na głównej przekątnej tych macierzy, wyeliminowano kolejne wskaźniki, dla których wartość diagonalna przekraczała liczbę 15 (wartość umowna), [Młodak, 2006].

Ostatecznie, biorąc pod uwagę przesłanki merytoryczne i statystyczne, ze zbioru zaproponowanych wstępnie 40 wskaźników do analizy wskaźnikowej oraz konstrukcji rankingów wybrano 26 zmiennych z podziałem na cztery obszary (tabela 1.).

\footnotetext{
${ }^{5}$ Rok 2014 nie zawierał pełnych danych w BDL.
} 
TABELA 1.

\section{Wykaz zmiennych diagnostycznych ${ }^{6}$}

\begin{tabular}{|c|c|}
\hline Obszary & Zmienne diagnostyczne \\
\hline \multirow{6}{*}{$\begin{array}{l}\text { Obszar I - } \\
\text { Demografia }\end{array}$} & 1.1. Przyrost naturalny (na 1000 ludności) \\
\hline & 1.2. Gęstość zaludnienia (ludność na $1 \mathrm{~km}^{2}$ ) \\
\hline & $\begin{array}{l}\text { 1.4. Wskaźnik obciażenia demograficznego - ludność w wieku } \\
\text { nieprodukcyjnym (na } 100 \text { osób w wieku produkcyjnym) }\end{array}$ \\
\hline & $\begin{array}{l}\text { 1.5. Zameldowania na pobyt stały międzypowiatowe } \\
\text { i zagraniczne (na } 1000 \text { ludności) }\end{array}$ \\
\hline & $\begin{array}{l}\text { 1.6. Wymeldowania na pobyt stały międzypowiatowe } \\
\text { i zagraniczne (na } 1000 \text { ludności) }\end{array}$ \\
\hline & 1.7. Pracujący (na 10 tys. ludności) \\
\hline \multirow{5}{*}{$\begin{array}{l}\text { Obszar II - } \\
\text { Podmioty gos- } \\
\text { podarcze i ry- } \\
\text { nek pracy }\end{array}$} & $\begin{array}{l}\text { 2.2. Jednostki nowo zarejestrowane w rejestrze REGON (na } 10 \text { tys. } \\
\text { ludności) }\end{array}$ \\
\hline & $\begin{array}{l}\text { 2.5. Podmioty średnie i duże (powyżej } 49 \text { zatrudnionych), (na } 10 \text { tys. } \\
\text { ludności) }\end{array}$ \\
\hline & 2.6. Stopa bezrobocia rejestrowanego $(\mathrm{w} \%)$ \\
\hline & $\begin{array}{l}\text { 2.7. Bezrobotni zarejestrowani pozostający bez pracy dłużej niż } 1 \\
\text { rok w bezrobotnych ogółem (udział) }\end{array}$ \\
\hline & 2.8. Bezrobotni w wieku 24 i mniej w bezrobotnych ogółem \\
\hline \multirow{7}{*}{$\begin{array}{l}\text { Obszar III - } \\
\text { Gospodarka }\end{array}$} & 3.1. Przeciętne miesięczne wynagrodzenia brutto (w zł) \\
\hline & $\begin{array}{l}\text { 3.2. Produkcja sprzedana przemysłu ogółem na } 1 \text { mieszkańca } \\
\text { (podmioty o liczbie pracujących }>9 \text { ), (w zł) }\end{array}$ \\
\hline & 3.3. Nakłady inwestycyjne w przedsiębiorstwach na 1 mieszkańca (w zł) \\
\hline & $\begin{array}{l}\text { 3.4. Wartość brutto środków trwałych w przedsiębiorstwach na } \\
1 \text { mieszkańca (w zł) }\end{array}$ \\
\hline & $\begin{array}{l}\text { 3.5. Dochody budżetu państwa z tytułu podatku PIT na } \\
1 \text { mieszkańca (w zl) }\end{array}$ \\
\hline & $\begin{array}{l}\text { 3.6. Dochody budżetu państwa z tytułu podatku CIT na } 1 \text { miesz- } \\
\text { kańca (w zł) }\end{array}$ \\
\hline & $\begin{array}{l}\text { 3.7. Udział wydatków inwestycyjnych powiatów w wydatkach } \\
\text { ogółem }(\mathrm{w} \%)\end{array}$ \\
\hline \multirow{8}{*}{$\begin{array}{l}\text { Obszar IV - } \\
\text { Warunki spo- } \\
\text { łeczne }\end{array}$} & 4.1. Mieszkania oddane do użytkowania (na 1000 ludności) \\
\hline & 4.2. Powierzchnia użytkowa mieszkań (w $\mathrm{m}^{2}$ na 1 mieszkańca) \\
\hline & 4.3. Liczba lekarzy i lekarzy dentystów (na 10 tys. ludności) \\
\hline & 4.4. Pielęgniarki i położne (na 10 tys. ludności) \\
\hline & 4.5. Udział dzieci w wieku do 3 lat objętych opieką w żłobkach \\
\hline & $\begin{array}{l}\text { 4.6. Dzieci w placówkach wychowania przedszkolnego (na } 1 \text { tys. } \\
\text { dzieci w wieku 3-5 lat) }\end{array}$ \\
\hline & 4.7. Mieszkańcy domów pomocy społecznej (na 10 tys. ludności) \\
\hline & $\begin{array}{l}\text { 4.8. Drogi gminne i powiatowe o twardej nawierzchni na } 100 \mathrm{~km}^{2} \\
(\mathrm{w} \mathrm{km})\end{array}$ \\
\hline
\end{tabular}

Źródło: opracowanie własne.

\footnotetext{
${ }^{6}$ Numeracja wskaźników nie jest liczbą porządkową.
} 
Ważnym elementem stosowania metod porównywania wielokryterialnego jest wyróżnienie w zbiorze wskaźników - stymulant ${ }^{7}$ i destymulant ${ }^{8}$. Podziału dokonano biorąc pod uwagę względy merytoryczne. Dodatkowo, w celu potwierdzenia wyboru, przeprowadzono analizę korelacji.

Spośród 26 wskaźników pięć z nich to destymulanty. Należą do nich:

- 1.4. Wskaźnik obciążenia demograficznego - ludność w wieku nieprodukcyjnym (na 100 osób w wieku produkcyjnym);

- 1.6. Wymeldowania na pobyt stały międzypowiatowe i zagraniczne (na 1000 ludności);

- 2.6. Stopa bezrobocia rejestrowanego (w \%);

- 2.7. Bezrobotni zarejestrowani pozostający bez pracy dłużej niż 1 rok w bezrobotnych ogółem (udział);

- 2.8. Bezrobotni w wieku 24 i mniej w bezrobotnych ogółem.

Dokonano również wstępnej analizy statystycznej zmiennych diagnostycznych z tabeli 1. Ich charakterystyki statystyczne w 2006 i 2013 roku przedstawiono w tabeli 2.

Duże współczynniki zmienności niektórych wskaźników, np.: 1.1., 1.2., 2.5. czy 4.5. są spowodowane odstającymi wartościami danych dla miast na prawach powiatów. Dla przykładu gęstość zaludnienia (zmienna 1.2.) w powiatach: m. Białystok, m. Łomża, m. Suwałki w roku 2006 wynosiła odpowiednio: 2887, 1940, 1057 osób na $1 \mathrm{~km}^{2}$, a w pozostałych powiatach nie przekraczała 62 osób na $1 \mathrm{~km}^{2}$.

Zróżnicowanie zakresów zmiennych diagnostycznych widoczne w tabeli 2. sugeruje konieczność ich ujednolicenia. W tym celu w dalszej części opracowania dane poddano procesowi normalizacji. Ponadto, dla wszystkich zmiennych zostały określone współczynniki wagowe $w_{k}(k=1,2, \ldots, 26)$. W literaturze przedmiotu można spotkać wiele sposobów na określenie wag [Malina, 2004; Panek, 2009]. W badaniach zjawisk społeczno-gospodarczych można wyróżnić podejście, w którym waga każdej zmiennej jest udział jej zmienności w zmienności całkowitej. Wówczas współczynnik wagowy ma postać: $w_{k}=\frac{v_{k}}{\sum v_{k}}$, gdzie $v_{k}$, to współczynnik zróżnicowania k-tej zmiennej [Malina, 2004].

Wagi przypisane poszczególnym wskaźnikom w rozważanych obszarach w 2006 oraz 2013 roku przedstawiono w tabelach: 3. i 4.

\footnotetext{
7 Stymulanty są zmiennymi, których wyższe wartości świadczą o lepszej sytuacji danego powiatu, a więc są pożądane.

${ }^{8}$ Destymulanty są zmiennymi, których niższe wartość świadczą o lepszej sytuacji danego powiatu. Wzrost tych wartości powoduje obniżenie pozycji powiatu w rankingu.
} 
TABELA 2.

Podstawowe statystyki opisowe dla wskaźników objaśniających rozwój społeczno-gospodarczy powiatów województwa podlaskiego w 2006 i 2013 roku

\begin{tabular}{|c|c|c|c|c|c|c|c|c|}
\hline \multirow{2}{*}{$\begin{array}{l}\text { Wskaź- } \\
\text { nik }\end{array}$} & \multicolumn{2}{|c|}{ Średnia } & \multicolumn{2}{|c|}{ Minimum } & \multicolumn{2}{|c|}{ Maksimum } & \multicolumn{2}{|c|}{$\begin{array}{c}\text { Współczynnik } \\
\text { zmienności }\end{array}$} \\
\hline & 2006 & 2013 & 2006 & 2013 & 2006 & 2013 & 2006 & 2013 \\
\hline 1.1. & $-1,21$ & $-1,21$ & $-6,70$ & $-6,70$ & 2,90 & 2,90 & 226,88 & 226,88 \\
\hline 1.2. & 378,12 & 377,00 & 25,00 & 24,00 & 2887,00 & 2891,00 & 217,36 & 217,62 \\
\hline 1.4. & 64,78 & 58,82 & 49,60 & 50,60 & 72,90 & 66,40 & 11,83 & 7,54 \\
\hline 1.5. & 7,71 & 6,08 & 4,13 & 3,26 & 16,89 & 14,50 & 49,00 & 53,65 \\
\hline 1.6. & 11,18 & 9,44 & 7,57 & 6,86 & 16,89 & 13,53 & 24,75 & 20,17 \\
\hline 1.7. & 131,47 & 146,00 & 65,00 & 85,00 & 259,00 & 277,00 & 42,69 & 41,44 \\
\hline 2.2 . & 58,35 & 62,59 & 35,00 & 41,00 & 149,00 & 106,00 & 47,98 & 29,81 \\
\hline 2.5 . & 0,38 & 0,41 & 0,07 & 0,06 & 2,63 & 2,71 & 159,07 & 151,01 \\
\hline 2.6. & 14,17 & 15,46 & 9,10 & 9,40 & 22,80 & 22,70 & 29,33 & 26,21 \\
\hline 2.7 . & 0,48 & 0,41 & 0,34 & 0,30 & 0,56 & 0,50 & 12,70 & 16,10 \\
\hline 2.8. & 0,25 & 0,23 & 0,16 & 0,12 & & 0,31 & 20,39 & 24,97 \\
\hline 3.1 . & 2197,50 & 3333,62 & 2018,18 & 2975,50 & 2828,33 & 3988,22 & 10,49 & 8,26 \\
\hline 3.2 . & 8200,00 & 9681,47 & 0,00 & 0,00 & 43097,00 & 28010,00 & 120,29 & 81,59 \\
\hline 3.3. & 1283,88 & 1539,68 & 237,00 & 442,20 & 3388,00 & 3331,20 & 68,47 & 57,09 \\
\hline 3.4 . & 12637,94 & 20831,89 & 2879,00 & 5468,30 & 30401,00 & 39511,60 & 64,65 & 58,04 \\
\hline 3.5 . & 691,54 & 1144,99 & 352,620 & 640,86 & 1659,81 & 2392,06 & 54,45 & 44,85 \\
\hline 3.6. & 189,36 & 316,28 & 29,201 & 21,38 & 669,78 & 1224,03 & 82,12 & 96,96 \\
\hline 3.7. & 19,48 & 16,98 & 13,100 & 9,20 & 32,00 & 29,10 & 23,91 & 25,87 \\
\hline 4.1. & 1,93 & 2,67 & 0,680 & 0,88 & 4,13 & 5,42 & 61,57 & 55,49 \\
\hline 4.2 . & 24,90 & 27,86 & 20,793 & 22,78 & 29,60 & 33,72 & 11,00 & 12,12 \\
\hline 4.3. & 30,05 & 35,24 & 3,132 & 3,73 & 115,13 & 132,18 & 90,89 & 81,48 \\
\hline 4.4. & 50,59 & 57,29 & 4,000 & 3,00 & 114,00 & 127,00 & 56,38 & 56,55 \\
\hline 4.5 . & 0,01 & 0,03 & 0,000 & 0,00 & 0,07 & 0,12 & 166,75 & 124,12 \\
\hline 4.6. & 278,00 & 645,76 & 17,000 & 479,00 & 744,00 & 900,00 & 64,83 & 17,97 \\
\hline 4.7. & 21,33 & 20,40 & 0,000 & 0,00 & 70,75 & 73,03 & 74,13 & 80,46 \\
\hline 4.8. & 72,51 & 393,39 & 29,00 & 23,20 & 272,10 & 888,50 & 97,30 & 58,65 \\
\hline
\end{tabular}

Źródło: opracowanie własne na podstawie danych z BDL z 2006 roku. 
TABELA 3. Współczynniki wagowe zmiennych diagnostycznych w Obszarach: I-IV przyjęte w roku 2006

Obszar I

\begin{tabular}{|c|c|c|c|c|c|c|c|}
\hline Wskaźnik & 1.1. & 1.2. & 1.4. & 1.5. & 1.6. & 1.7. & \\
\hline Waga & 0,40 & 0,38 & 0,02 & 0,09 & 0,04 & 0,07 & \\
\hline \multicolumn{7}{|c|}{ Obszar II } & \\
\hline Wskaźnik & 2.2. & 2.5. & 2.6. & 2.7. & 2.8. & & \\
\hline Waga & 0,18 & 0,59 & 0,11 & 0,05 & 0,08 & & \\
\hline \multicolumn{8}{|c|}{ Obszar III } \\
\hline Wskaźnik & 3.1. & 3.2 . & 3.3. & 3.4. & 3.5 . & 3.6. & 3.7. \\
\hline Waga & 0,025 & 0,283 & 0,161 & 0,152 & 0,128 & 0,194 & 0,056 \\
\hline
\end{tabular}

Obszar IV

\begin{tabular}{|l|c|c|c|c|c|c|c|c|}
\hline Wskaźnik & 4.1. & 4.2. & 4.3. & 4.4. & 4.5. & 4.6. & 4.7. & 4.8. \\
\hline Waga & 0,10 & 0,02 & 0,15 & 0,09 & 0,27 & 0,10 & 0,12 & 0,16 \\
\hline
\end{tabular}

Źródło: opracowanie własne

TABELA 4.

Współczynniki wagowe zmiennych diagnostycznych w Obszarach: I-IV przyjęte w roku 2013

Obszar I

\begin{tabular}{|l|c|c|c|c|c|c|}
\hline Wskaźnik & 1.1. & 1.2. & 1.4. & 1.5. & 1.6. & 1.7. \\
\hline Waga & 0,40 & 0,38 & 0,01 & 0,09 & 0,04 & 0,07 \\
\hline
\end{tabular}

Obszar II

\begin{tabular}{|l|c|c|c|c|c|}
\hline Wskaźnik & 2.2. & 2.5. & 2.6. & 2.7. & 2.8. \\
\hline Waga & 0,12 & 0,61 & 0,11 & 0,06 & 0,10 \\
\hline
\end{tabular}

Obszar III

\begin{tabular}{|l|c|c|c|c|c|c|c|}
\hline Wskaźnik & 3.1. & 3.2. & 3.3. & 3.4. & 3.5. & 3.6. & 3.7. \\
\hline Waga & 0,02 & 0,22 & 0,15 & 0,16 & 0,12 & 0,26 & 0,07 \\
\hline
\end{tabular}

Obszar IV

\begin{tabular}{|l|c|c|c|c|c|c|c|c|}
\hline Wskaźnik & 4.1. & 4.2. & 4.3. & 4.4. & 4.5. & 4.6. & 4.7. & 4.8. \\
\hline Waga & 0,11 & 0,02 & 0,15 & 0,11 & 0,24 & 0,03 & 0,15 & 0,19 \\
\hline
\end{tabular}

Źródło: opracowanie własne 


\section{Ranking powiatów metodą TOPSIS}

Pierwszą z metod zastosowaną w pracy jest klasyczny algorytm TOPSIS9 umożliwiający opisanie złożonego zjawiska, którego nie można bezpośrednio zmierzyć [Roszkowska, Misiewicz, Karwowska, 2014, s. 168-190]. W metodzie tej analizę poziomu badanego zjawiska przy użyciu zbioru wskaźników zastępuje się analizą zagregowanej wielkości, nazywanej miernikiem syntetycznym. Jego konstrukcja polega na wyznaczeniu odległości każdego wielocechowego obiektu od wzorca i antywzorca rozwoju. Efektem końcowym jest liniowe uporządkowanie obiektów, a zatem stworzenie rankingu opisującego zjawisko.

Przy wyznaczaniu miernika syntetycznego metodą TOPSIS wyróżnia się poniższe etapy postępowania [Hwang, Yoon, 1981; Roszkowska, 2009; Wysocki, 2010].

1. Konstrukcja macierzy danych $X=\left[x_{i k}\right]$, gdzie $x_{i k}$ jest wartością $k$-tego wskaźnika dla $i$-tego powiatu, dla $i=1,2, \ldots, 17$ oznaczającego numer powiatu oraz $k=1,2, \ldots, 26$ oznaczającego numer wskaźnika.

2. Normalizacja wartości zmiennych zgodnie z procedurą:

- dla stymulant

$$
z_{i k}=\frac{x_{i k}-\min _{i}\left\{x_{i k}\right\}}{\max _{i}\left\{x_{i k}\right\}-\min _{i}\left\{x_{i k}\right\}},
$$

- dla destymulant

$$
z_{i k}=\frac{\max _{i}\left\{x_{i k}\right\}-x_{i k}}{\max _{i}\left\{x_{i k}\right\}-\min _{i}\left\{x_{i k}\right\}},
$$

gdzie:

$\max _{i}\left\{x_{i k}\right\}$ - maksymalna wartość k-tego wskaźnika,

$\min _{i}\left\{x_{i k}\right\}$ - minimalna wartość k-tego wskaźnika.

3. Wyznaczenie znormalizowanej macierzy z uwzględnieniem wektora wag, której wartości obliczono według wzoru:

$$
v_{i k}=w_{k} z_{i k}
$$

gdzie $w_{k}$ jest waga $k$ - tego wskaźnika, $\sum_{k=1}^{m} w_{k}=1$.

4. Wskazanie rozwiazzania idealnego (wzorca) $v^{+}=\left\{v_{1}^{+}, v_{2}^{+}, \ldots, v_{m}^{+}\right\}$oraz antyidealnego (antywzorca) $v^{-}=\left\{v_{1}^{-}, v_{2}^{-}, \ldots, v_{m}^{-}\right\}$zgodnie $\mathrm{z}$ formułami:

$$
v_{k}^{+}=\max _{i}\left\{x_{i k}\right\}, v_{k}^{-}=\min _{i}\left\{x_{i k}\right\} \text {. }
$$

5. Obliczenie odległości euklidesowej od wzorca oraz antywzorca zgodnie ze wzorami:

\footnotetext{
${ }^{9}$ Skrót ten pochodzi z angielskiej nazwy: Technique for Order Preference by Similarity to an Ideal Solution.
} 


$$
d_{i}^{+}=\sqrt{\sum_{k=1}^{m}\left(v_{i k}-v_{k}^{+}\right)^{2}} \mathrm{i} d_{i}^{-}=\sqrt{\sum_{k=1}^{m}\left(v_{i k}-v_{k}^{-}\right)^{2}} .
$$

6. Wyznaczenie wartości syntetycznego miernika zgodnie z formułą:

$$
q_{i}=\frac{d_{i}^{-}}{d_{i}^{-}+d_{i}^{+}} \text {dla } i=1,2, \ldots, n=17 .
$$

Wartość syntetycznego miernika qi mieści się w przedziale obustronnie domkniętym od 0 do 1 . Im jego wartość jest bliższa jedynce, tym wyższa pozycja $i$-tego powiatu $\mathrm{w}$ rankingu.

$\mathrm{Na}$ podstawie metody TOPSIS, biorąc pod uwagę wartość obliczonego miernika syntetycznego $\left(q_{\mathrm{i}}\right)$, wyznaczone zostały pozycje powiatów w każdym z czterech badanych obszarów w 2006 i 2013 roku. Wyniki zaprezentowano na wykresach: 3.-6.

\section{Obszar I - Demografia}

WYKRES 3.

Zmiany pozycji powiatów w rankingach w 2006 i 2013 roku, w Obszarze I otrzymane metodą TOPSIS
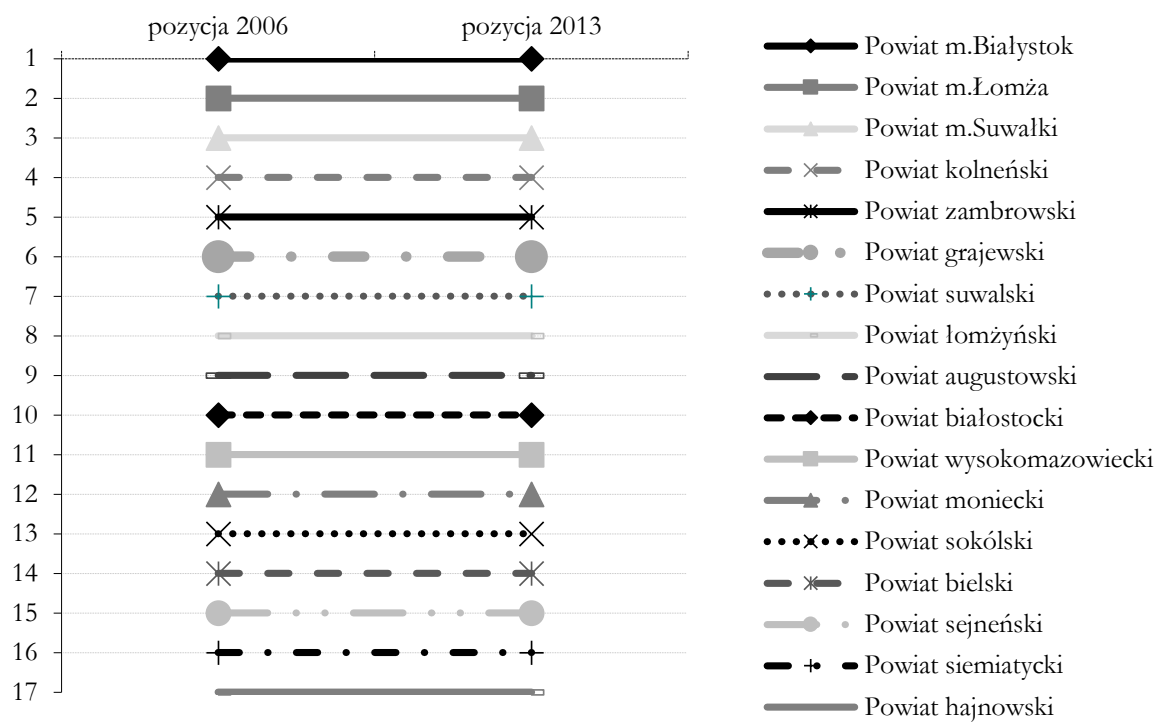

Źródło: opracowanie własne na podstawie wyników otrzymanych metodą TOPSIS.

Jak wynika z wykresu 3., w 2006 i 2013 roku, w obrębie Obszaru I nie odnotowano żadnych zmian pozycji powiatów w rankingu pod względem rozwoju społeczno-gospodarczego. 
Obszar II - Podmioty gospodarcze i rynek pracy

\section{Zmiany pozycji powiatów w rankingach w 2006 i 2013 roku, w Obszarze II otrzymane metodą TOPSIS}

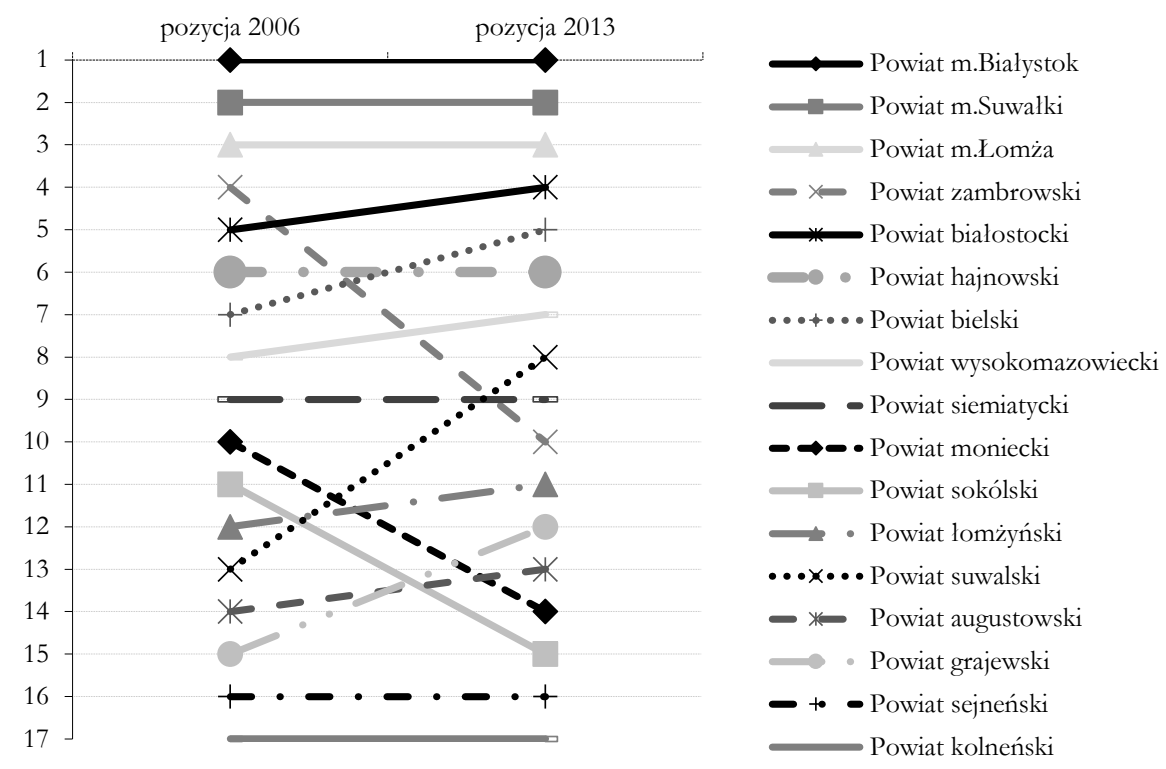

Źródło: opracowanie własne na podstawie wyników otrzymanych metodą TOPSIS.

Na podstawie wykresu 4. można zauważyć dość duże różnice w pozycjach powiatów w porównywanych latach. Największy skok w górę o 5 miejsc zanotował powiat suwalski, jak również powiat grajewski (o 3 miejsca). Natomiast największe spadki zanotowały powiaty: zambrowski - o 6 miejsc, moniecki i sokólski - o 4 miejsca. W celu zdiagnozowania, które wskaźniki z Obszaru II miały największe znaczenie dla budowy rankingów, poddano je szczegółowej analizie. Można jednoznacznie stwierdzić, że na miejsce powiatu w rankingu największy wpływ miały wskaźniki:

- 2.2. Jednostki nowo zarejestrowane w rejestrze REGON (na 10 tys. ludności);

- 2.6. Stopa bezrobocia rejestrowanego (w \%).

\section{Obszar III - Gospodarka}

Rankingi sporządzone metodą TOPSIS w obrębie Obszaru III, w dwóch porównywanych latach wskazują na dość duże przetasowania wśród porządkowanych powiatów. Zmiany pozycji powiatów zilustrowano na wykresie 5. 


\section{WYKRES 5.}

\section{Zmiany pozycji powiatów w rankingach w 2006 i 2013 roku, w Obszarze III otrzymane metodą TOPSIS}
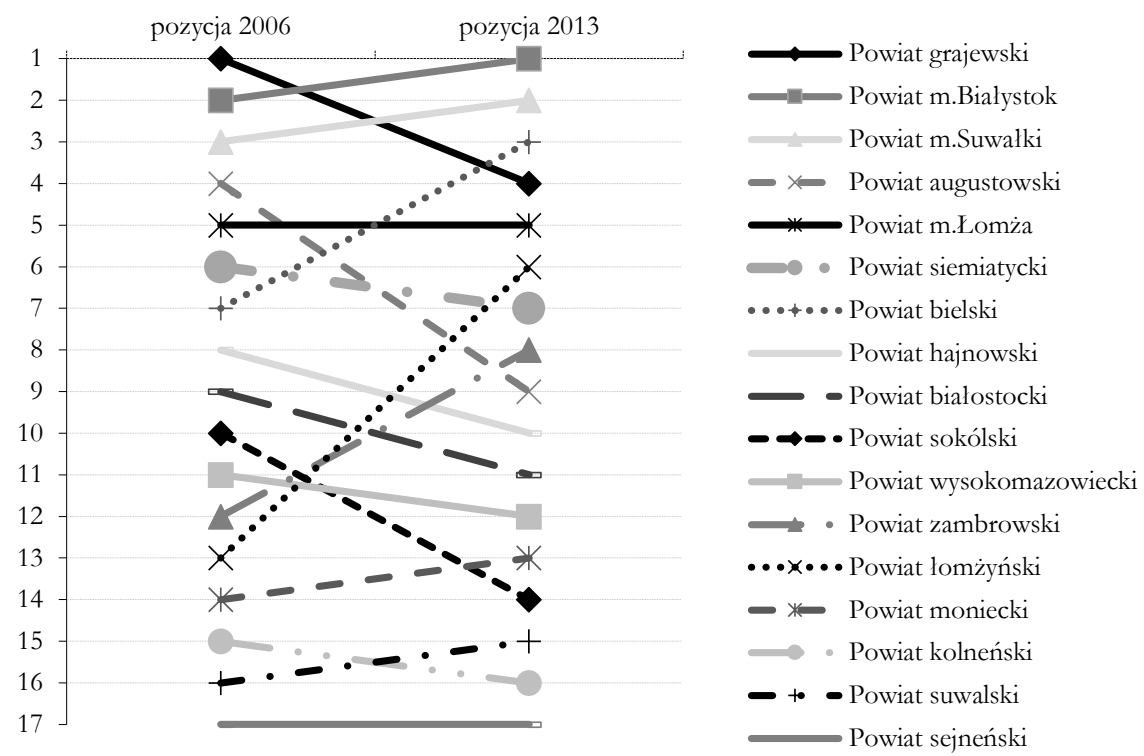

Źródło: opracowanie własne na podstawie wyników otrzymanych metodą TOPSIS.

W Obszarze III największy wzrost zanotował powiat łomżyński - o 7 miejsc, natomiast największy spadek (o 5 miejsc) zanotował powiat augustowski. Analizując wskaźniki decydujące o pozycji w rankingu w Obszarze III - Gospodarka, należy zauważyć, że miernikami, które najbardziej różnicowały powiaty były:

- 3.3. Nakłady inwestycyjne w przedsiębiorstwach na 1 mieszkańca (w zł);

- 3.2. Produkcja sprzedana przemysłu ogółem na 1 mieszkańca (podmioty o liczbie pracujących $>9$ ) (w zl);

- $\quad$ 3.6. Dochody budżetu państwa z tytułu podatku CIT na 1 mieszkańca (w zł). 


\section{Obszar IV - Warunki społeczne}

WYKRES 6.

\section{Zmiany pozycji powiatów w rankingach w 2006 i 2013 roku, w Obszarze IV} otrzymane metodą TOPSIS
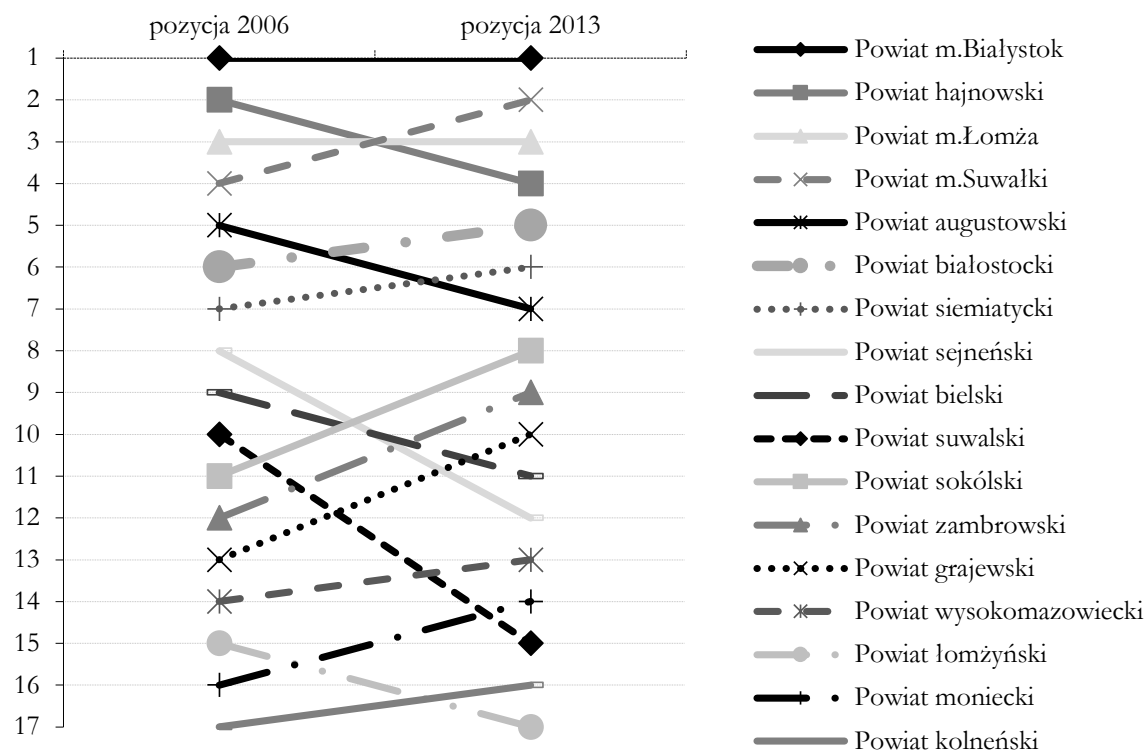

Źródło: opracowanie własne na podstawie wyników otrzymanych metodą TOPSIS.

Z wykresu 6. wynika, że w 2006 i 2013 roku, w obrębie Obszaru IV miały miejsce znaczące zmiany w pozycjach powiatów uzyskanych metodą TOPSIS. Tylko dwa spośród 17 powiatów zachowały swoje miejsca. Na taką sytuację największy wpływ miały zmienne:

- 4.6. Dzieci w placówkach wychowania przedszkolnego (na 1 tys. dzieci w wieku 3-5 lat);

- 4.5. Udział dzieci w wieku do 3 lat objętych opieką w żłobkach;

- 4.3. Liczba lekarzy i lekarzy dentystów (na 10 tys. ludności);

- 4.1. Mieszkania oddane do użytkowania (na 1000 ludności).

W Obszarze IV największa poprawa dotyczyła powiatów: grajewskiego, sokólskiego i zambrowskiego i był to awans o 3 miejsca. Swoją pozycję w stosunku do pozostałych poprawiły także powiaty: $\mathrm{m}$. Suwałki i moniecki (o 2 lokaty), siemiatycki, białostocki, wysokomazowiecki i kolneński (o 1 lokatę). Natomiast sześć powiatów pogorszyło swoja pozycję, przy czym największy spadek dotyczył powiatów: suwalskiego (o 5 lokat), sejneńskiego (o 4 lokaty), a spadek o dwie lokaty zanotowały powiaty: hajnowski, augustowski, bielski i łomżyński. 


\section{Ranking powiatów metodą wzorcową Hellwiga}

Drugą z metod wykorzystaną w pracy jest, najczęściej stosowana w praktyce, metoda wzorcowa zaproponowana przez Z. Hellwiga [Hellwig, 1968], nazywana od twórcy miarą Hellwiga. Pozwala ona na zbudowanie miary syntetycznej, uwzględniającej łączne oddziaływanie na badane zjawisko wielu wskaźników charakteryzujących różne jego aspekty. Podobnie jak w metodzie TOPSIS, procedurę kończy ustalenie hierarchii obiektów ze względu na zjawisko poddane badaniu.

Konstrukcja miary Hellwiga kolejno obejmuje poniższe etapy [Młodak, 2006; Panek, 2009].

1. Normalizacja wartości zmiennych zgodnie z procedura:

$$
z_{i k}=\frac{x_{i k}-\bar{x}_{k}}{S_{k}}
$$

gdzie:

$$
\begin{aligned}
& \bar{x}_{k}=\frac{\sum_{i=1}^{m} x_{i}}{m} \text { oznacza średnią arytmetyczną k-tego wskaźnika dla: } \\
& k=1,2, \ldots, m, S_{k}(x)=\sqrt{\frac{\sum_{i=1}^{m}\left(x_{i k}-\bar{x}_{k}\right)^{2}}{m}} \text { - odchylenie standardowe. }
\end{aligned}
$$

2. Wyznaczenie obiektu wzorcowego [z.一k], którego współrzędne wyznacza się zgodnie z formuła:

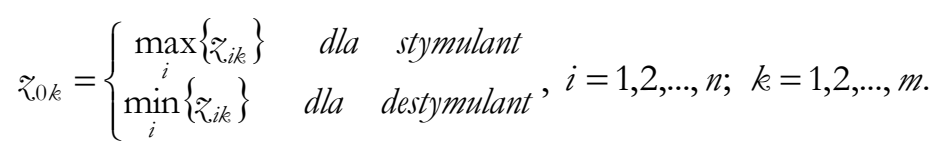

3. Obliczenie dla każdego obiektu jego odległości od obiektu wzorcowego, stosując metrykę euklidesową z uwzględnieniem wag poszczególnych zmiennych postaci:

$$
d_{i 0}=\sqrt{\sum_{k=1}^{m} w_{k}\left(z_{i k}-z_{0 k}\right)^{2}} .
$$

4. Wyznaczenie syntetycznej miary $q_{i}$ dla $i$-tego powiatu zgodnie ze wzorem:

$$
q_{i}=1-\frac{d_{i 0}}{d_{0}}
$$

gdzie:

$d_{0}=\bar{d}+2 S_{d}$, 
$\bar{d}$ - średnia arytmetyczna odległości $d_{i 0}$,

$S_{d}$ - odchylenie standardowe odległości od obiektu wzorcowego.

Wyższe wartości $q_{i}$, świadczą o wyższej pozycji w rankingu $i$-tego powiatu.

Badaniu metodą Hellwiga poddano Obszary: I-IV pod względem oddziaływania danych diagnostycznych na zmiany pozycji w rankingach powiatów w 2006 i 2013 roku. Wyniki analizy zobrazowano na wykresach: 7.-10.

\section{Obszar I - Demografia}

WYKRES 7.

Zmiany pozycji powiatów w rankingach w 2006 i 2013 roku, w Obszarze I otrzymane metodą Hellwiga
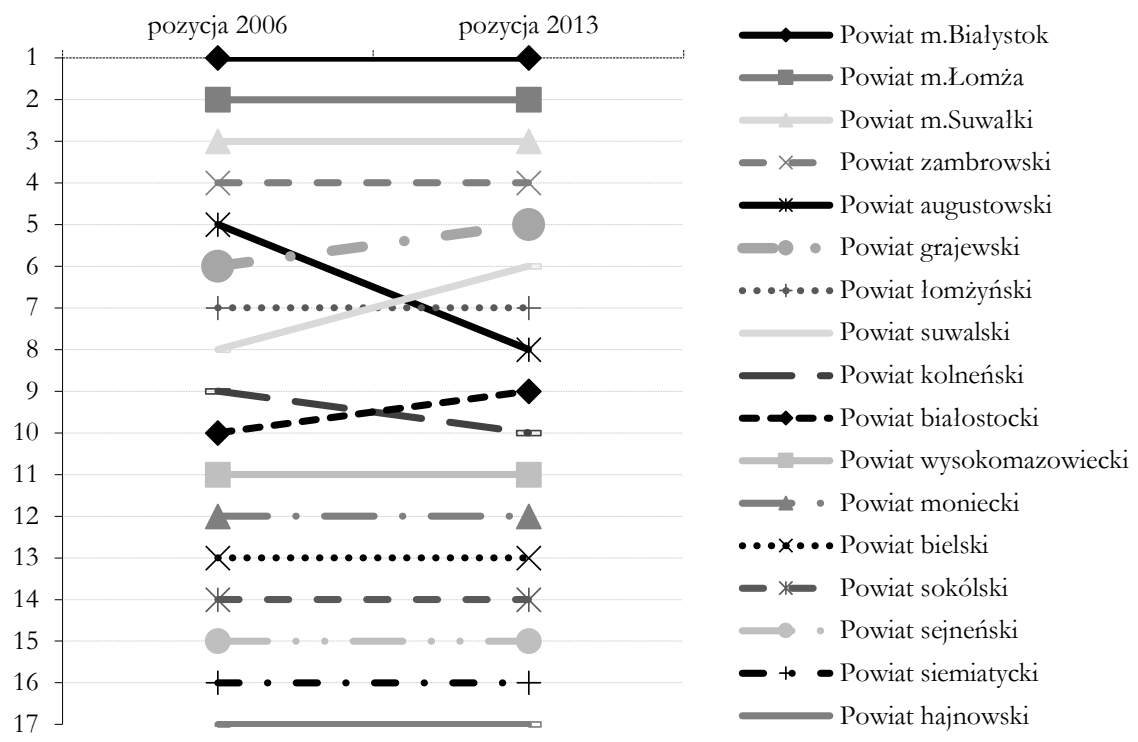

Źródło: opracowanie własne na podstawie wyników otrzymanych metodą Hellwiga.

Z wykresu 7. wynika, że w Obszarze I aż 12 powiatów zachowało swoje pozycje. Największe zmiany w porównywanym 2006 i 2013 roku dotyczyły powiatu augustowskiego - spadek o 3 pozycje oraz przesunięcie się powiatu suwalskiego o 2 pozycje w górę. $\mathrm{Na}$ zmiany rankingów w Obszarze I największy wpływ miał wskaźnik:

- 1.5. Zameldowania na pobyt stały międzypowiatowe i zagraniczne (na 1000 ludności). 


\section{Obszar II - Podmioty gospodarcze i rynek pracy}

Wykres 8. przedstawia zmiany pozycji powiatów w rankingach w 2006 i 2013 roku, w Obszarze II otrzymane metodą wzorcową Hellwiga.

WYKRES 8.

\section{Zmiany pozycji powiatów w rankingach w 2006 i 2013 roku, w Obszarze II otrzymane metodą Hellwiga}
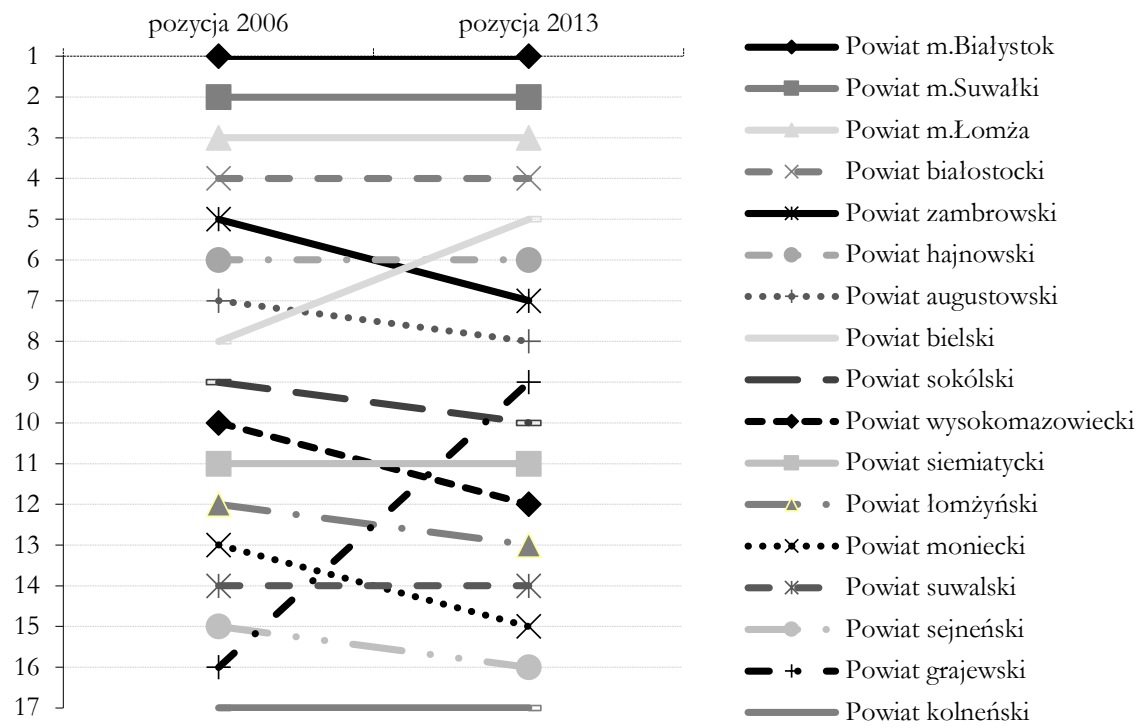

Źródło: opracowanie własne na podstawie wyników otrzymanych metodą Hellwiga.

Najwyższy wzrost o 7 lokat w rankingu zanotował powiat grajewski, zaś powiat bielski poprawił swoja pozycję o 3 lokaty. Z analizy wskáników tego obszaru wynika, że przyczyną takiej sytuacji była liczba średnich i dużych przedsiębiorstw na 10 tys. ludności (wskaźnik 2.5.) oraz liczba jednostek nowo zarejestrowanych w rejestrze REGON na 10 tys. ludności (wskaźnik 2.2.). W obszarze tym siedem powiatów pogorszyło swoją sytuację. Największy spadek (o 2 lokaty) dotyczył trzech powiatów: zambrowskiego, wysokomazowieckiego i monieckiego. 


\section{Obszar III - Gospodarka}

WYKRES 9.

\section{Zmiany pozycji powiatów w rankingach w 2006 i 2013 roku, w Obszarze III otrzymane metodą Hellwiga}

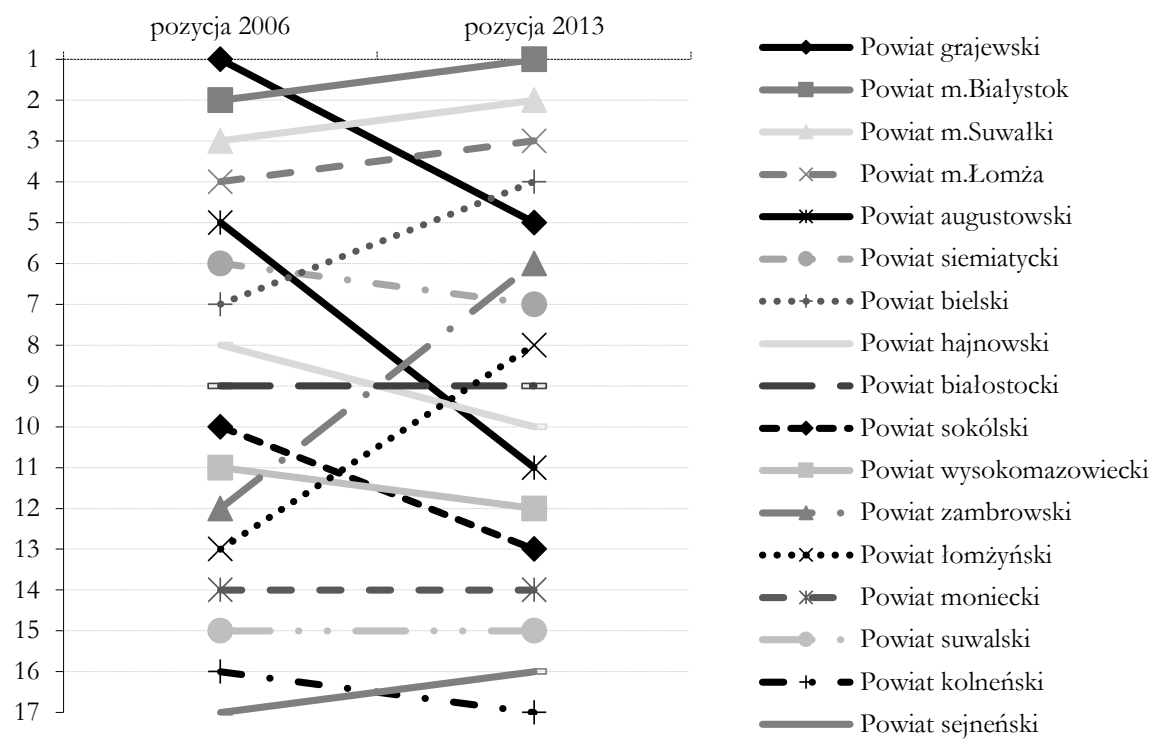

Źródło: opracowanie własne na podstawie wyników otrzymanych metodą Hellwiga.

Jak wynika z wykresu 9., w obrębie Obszaru III zanotowano dość duże zmiany w rankingach stworzonych metodą Hellwiga dla 2006 i 2013 roku. Na zmiany te miały wpływ te same wskaźniki, które różnicowały powiaty w rankingu uzyskanym metodą TOPSIS, ale kolejność ich wpływu była odwrotna:

- 3.6. Dochody budżetu państwa z tytułu podatku CIT na 1 mieszkańca (w zł);

- 3.2. Produkcja sprzedana przemysłu ogółem na 1 mieszkańca (podmioty o liczbie pracujących $>9)$, (w zł);

- 3.3. Nakłady inwestycyjne w przedsiębiorstwach na 1 mieszkańca (w zł);

- 3.4. Wartość brutto środków trwałych w przedsiębiorstwach na 1 mieszkańca (w zł).

Największa poprawa dotyczyła powiatu zambrowskiego z miejsca 12. na 6. i łomżyńskiego (o 5 lokat), zaś największy spadek objął powiat grajewski z miejsca 1. na 5. oraz augustowski $-\mathrm{z}$ miejsca 5 . na 11 . 


\section{Obszar IV - Warunki społeczne}

WYKRES 10.

Zmiany pozycji powiatów w rankingach w 2006 i 2013 roku, w Obszarze IV otrzymane metodą Hellwiga
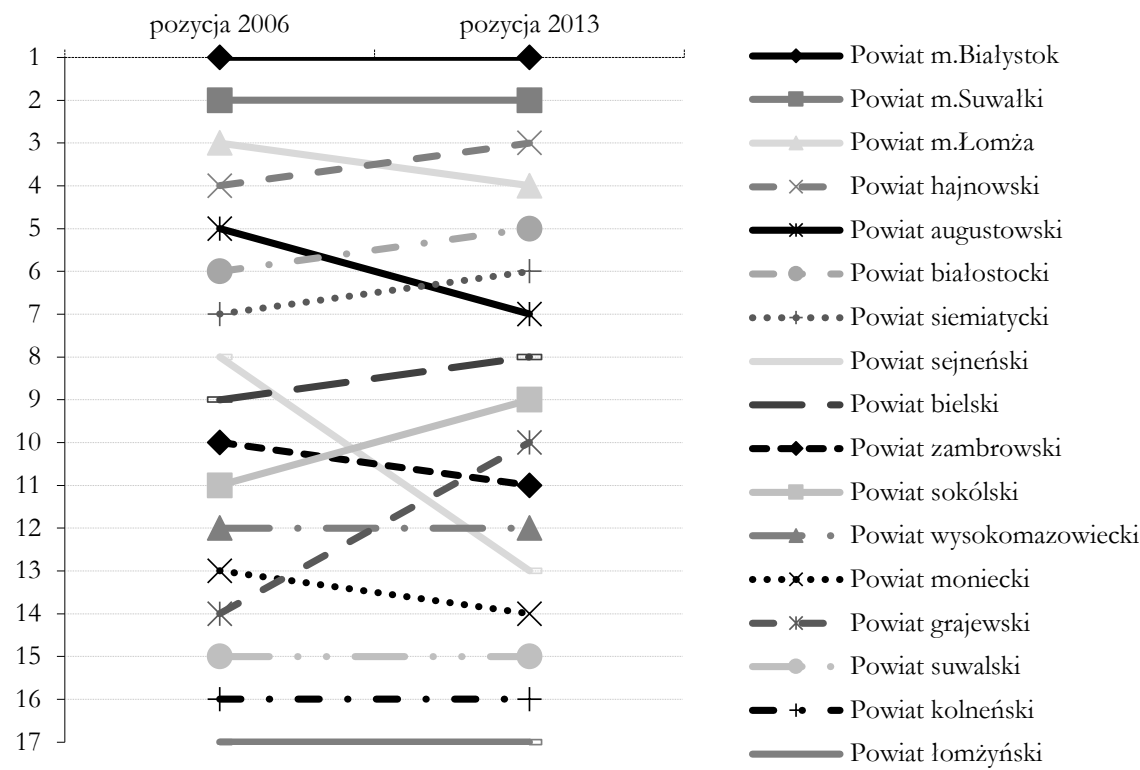

Źródło: opracowanie własne na podstawie wyników otrzymanych metodą Hellwiga.

Wykres 10. wskazuje na niewielkie zmiany lokat w rankingach, w obrębie Obszaru IV. Sześć spośród 17 powiatów zachowały swoje miejsca w rankingach, w porównywanym 2006 i 2013 roku. Największy wzrost zanotował powiat grajewski (4 pozycje do góry), natomiast największy spadek powiat sejneński (5 pozycji w dół). Na zmiany te miały wpływ następujące wskaźniki:

- 4.6. Dzieci w placówkach wychowania przedszkolnego (na 1 tys. dzieci w wieku 3-5 lat);

- 4.5. Udział dzieci w wieku do 3 lat objętych opieką w żłobkach;

- 4.3. Liczba lekarzy i lekarzy dentystów (na 10 tys. ludności);

- 4.1. Mieszkania oddane do użytkowania (na 1000 ludności).

\section{Analiza porównawcza otrzymanych wyników}

Wyniki uporządkowania powiatów pod względem rozwoju społeczno-gospodarczego z podziałem na Obszary: I-IV za pomocą metody Hellwiga $(\mathrm{H})$ oraz metody TOPSIS (TP) uzyskane w 2006 oraz 2013 roku zostały przedstawione w tabelach: 5. i 6. 
TABELA 5.

Uporządkowanie powiatów województwa podlaskiego ze względu na poziom rozwoju społeczno-gospodarczego w ramach obszarów, w roku 2006 porównanie metod

\begin{tabular}{|c|c|c|c|c|c|c|c|c|}
\hline \multirow[t]{2}{*}{ Powiaty } & \multicolumn{2}{|c|}{ Obszar I } & \multicolumn{2}{|c|}{ Obszar II } & \multicolumn{2}{|c|}{$\begin{array}{c}\text { Obszar } \\
\text { III }\end{array}$} & \multicolumn{2}{|c|}{ Obszar IV } \\
\hline & TP & $\mathbf{H}$ & TP & $\mathbf{H}$ & TP & $\mathbf{H}$ & TP & $\mathbf{H}$ \\
\hline Powiat m. Białystok & 1 & 1 & 1 & 1 & 2 & 2 & 1 & 1 \\
\hline Powiat m. Suwałki & 3 & 3 & 2 & 2 & 3 & 3 & 4 & 2 \\
\hline Powiat m. Łomża & 2 & 2 & 3 & 3 & 5 & 4 & 3 & 3 \\
\hline Powiat białostocki & 10 & 10 & 5 & 4 & 9 & 9 & 6 & 6 \\
\hline Powiat augustowski & 9 & 5 & 14 & 7 & 4 & 5 & 5 & 5 \\
\hline Powiat hajnowski & 17 & 17 & 6 & 6 & 8 & 8 & 2 & 4 \\
\hline Powiat zambrowski & 5 & 4 & 4 & 5 & 12 & 12 & 12 & 10 \\
\hline Powiat grajewski & 6 & 6 & 15 & 16 & 1 & 1 & 13 & 14 \\
\hline Powiat bielski & 14 & 13 & 7 & 8 & 7 & 7 & 9 & 9 \\
\hline Powiat siemiatycki & 16 & 16 & 9 & 11 & 6 & 6 & 7 & 7 \\
\hline Powiat wysokomazowiecki & 11 & 11 & 8 & 10 & 11 & 11 & 14 & 12 \\
\hline Powiat sokólski & 13 & 14 & 11 & 9 & 10 & 10 & 11 & 11 \\
\hline Powiat suwalski & 7 & 8 & 13 & 14 & 16 & 15 & 10 & 15 \\
\hline Powiat łomżyński & 8 & 7 & 12 & 12 & 13 & 13 & 15 & 17 \\
\hline Powiat moniecki & 12 & 12 & 10 & 13 & 14 & 14 & 16 & 13 \\
\hline Powiat kolneński & 4 & 9 & 17 & 17 & 15 & 16 & 17 & 16 \\
\hline Powiat sejneński & 15 & 15 & 16 & 15 & 17 & 17 & 8 & 8 \\
\hline $\begin{array}{l}\text { Współczynnik korelacji } \\
\text { rang Spearmana }\end{array}$ & \multicolumn{2}{|c|}{0,944} & \multicolumn{2}{|c|}{0,907} & \multicolumn{2}{|c|}{0,995} & \multicolumn{2}{|c|}{0,931} \\
\hline $\begin{array}{c}\text { Współczynnik korelacji } \tau \\
\text { Kendalla }\end{array}$ & \multicolumn{2}{|c|}{0,853} & \multicolumn{2}{|c|}{0,809} & \multicolumn{2}{|c|}{0,971} & \multicolumn{2}{|c|}{0,809} \\
\hline
\end{tabular}

Źródło: opracowanie własne na podstawie wyników otrzymanych metodą Hellwiga $(\mathrm{H})$ oraz TOPSIS (TP).

Rezultaty otrzymane w roku 2006 (tabela 5.) wskazują na zbieżność uzyskanych rankingów. Zgodność klasyfikacji ze względu na obie metody występuje w 10 powiatach w odniesieniu do Obszaru I (Demografia), w 6 powiatach w przypadku Obszaru II (Podmioty gospodarcze i rynek pracy), w 13 powiatach dla Obszaru III (Gospodarka) oraz w 7 dla Obszaru IV (Warunki społeczne).

Oceny zgodności użytych metod dokonano na podstawie współczynników korelacji rang Spearmana oraz Kendalla. W obu przypadkach współczynniki korelacji rang moga przyjmować wartości między -1 a 1, przy czym wartość współczynnika bliska 1 oznacza silną „zgodność” uporządkowania rang.

Współczynniki korelacji rang Spearmana w poszczególnych obszarach wyniosły odpowiednio dla: Obszaru I - 0,944, Obszaru II - 0,907, Obszaru III - 0,995, Obszaru 
IV - 0,931. Najwyższą zgodność klasyfikacji uzyskano więc dla Obszaru III (Gospodarka), najniższa zaś dla Obszaru II (Podmioty gospodarcze i rynek pracy). Otrzymane wyniki potwierdził współczynnik rang Kendalla, który dał podobne rezultaty.

TABELA 6.

Uporządkowanie powiatów województwa podlaskiego ze względu na poziom rozwoju społeczno-gospodarczego w ramach obszarów, w roku 2013 - porównanie metod

\begin{tabular}{|c|c|c|c|c|c|c|c|c|}
\hline \multirow[t]{2}{*}{ Powiaty } & \multicolumn{2}{|c|}{ Obszar I } & \multicolumn{2}{|c|}{ Obszar II } & \multicolumn{2}{|c|}{$\begin{array}{l}\text { Obszar } \\
\text { III }\end{array}$} & \multicolumn{2}{|c|}{ Obszar IV } \\
\hline & TP & $\mathbf{H}$ & TP & $\mathbf{H}$ & TP & $\mathbf{H}$ & TP & $\mathbf{H}$ \\
\hline Powiat m. Białystok & 1 & 1 & 1 & 1 & 1 & 1 & 1 & 1 \\
\hline Powiat m. Suwałki & 3 & 3 & 2 & 2 & 2 & 2 & 2 & 2 \\
\hline Powiat m. Łomża & 2 & 2 & 3 & 3 & 5 & 3 & 3 & 4 \\
\hline Powiat białostocki & 10 & 9 & 4 & 4 & 11 & 9 & 5 & 5 \\
\hline Powiat grajewski & 6 & 5 & 12 & 9 & 4 & 5 & 10 & 10 \\
\hline Powiat zambrowski & 5 & 4 & 10 & 7 & 8 & 6 & 9 & 11 \\
\hline Powiat bielski & 14 & 13 & 5 & 5 & 3 & 4 & 11 & 8 \\
\hline Powiat hajnowski & 17 & 17 & 6 & 6 & 10 & 10 & 4 & 3 \\
\hline Powiat augustowski & 9 & 8 & 13 & 8 & 9 & 11 & 7 & 7 \\
\hline Powiat siemiatycki & 16 & 16 & 9 & 11 & 7 & 7 & 6 & 6 \\
\hline Powiat łomżyński & 8 & 7 & 11 & 13 & 6 & 8 & 17 & 17 \\
\hline Powiat wysokomazowiecki & 11 & 11 & 7 & 12 & 12 & 12 & 13 & 12 \\
\hline Powiat suwalski & 7 & 6 & 8 & 14 & 15 & 15 & 15 & 15 \\
\hline Powiat sokólski & 13 & 14 & 15 & 10 & 14 & 13 & 8 & 9 \\
\hline Powiat kolneński & 4 & 10 & 17 & 17 & 16 & 17 & 16 & 16 \\
\hline Powiat moniecki & 12 & 12 & 14 & 15 & 13 & 14 & 14 & 14 \\
\hline Powiat sejneński & 15 & 15 & 16 & 16 & 17 & 16 & 12 & 13 \\
\hline $\begin{array}{l}\text { Współczynnik korelacji } \\
\text { rang Spearmana }\end{array}$ & \multicolumn{2}{|c|}{0,946} & \multicolumn{2}{|c|}{0,831} & \multicolumn{2}{|c|}{0,968} & \multicolumn{2}{|c|}{0,978} \\
\hline $\begin{array}{c}\text { Współczynnik korelacji } \tau \\
\text { Kendalla }\end{array}$ & \multicolumn{2}{|c|}{0,897} & \multicolumn{2}{|c|}{0,706} & \multicolumn{2}{|c|}{0,853} & \multicolumn{2}{|c|}{0,912} \\
\hline
\end{tabular}

Źródło: opracowanie własne na podstawie wyników otrzymanych metodą Hellwiga (H) oraz TOPSIS (TP).

W tabeli 6. została przedstawiona analiza wyników uzyskanych dwiema metodami dla roku 2013. Również w tym przypadku zgodność klasyfikacji otrzymanych metodami Hellwiga oraz TOPSIS we wszystkich obszarach była zbliżona: w Obszarach I i II w 8 powiatach, w Obszarze III w 6 powiatach, natomiast w Obszarze IV w 10 powiatach. We wszystkich obszarach zarówno współczynniki korelacji rang Spearmana, jak i współczynniki rang Kendalla były wyższe od 0,70. Oznacza to, że rankingi uzyskane w 2013 roku można uznać za zgodne. 


\section{Podsumowanie}

W pracy dokonano analizy poziomu rozwoju społeczno-gospodarczego powiatów województwa podlaskiego w 2006 oraz 2013 roku w takich obszarach, jak: demografia, podmioty gospodarcze i rynek pracy, gospodarka oraz warunki społeczne. Zastosowanie metody TOPSIS oraz metody wzorca rozwoju Hellwiga umożliwiło ocenę stanu powiatów województwa podlaskiego. Obie metody pozwoliły ustalić rankingi powiatów w badanych latach w obrębie wymienionych obszarów. Uzyskane metodą TOPSIS oraz Hellwiga uporządkowania w ramach analizowanych obszarów były podobne. Tę zgodność dodatkowo potwierdziły wysokie współczynniki korelacji rang Spearmana oraz Kendalla.

W obu przedstawionych rankingach nie można było zaobserwować znaczących zmian lokat ocenianych powiatów w roku 2013 w stosunku do roku 2006. Na najwyższej pozycji $\mathrm{w}$ obu analizowanych latach uplasowały się miasta na prawach powiatu, $\mathrm{tj} .:$ Białystok, Suwałki i Łomża. One również z niewielkimi odstępstwami zajęły czołowe lokaty w rankingach otrzymanych w obrębie obszarów. Natomiast na ostatnich miejscach w rankingach znajdowały się powiaty: kolneński oraz sejneński.

Jak wynika z przeprowadzonej analizy, w województwie podlaskim znalazły się powiaty, które podlegały dynamicznemu rozwojowi, szczególnie w obrębie obszarów: II i III, to powiaty: grajewski, łomżyński i bielski. Powiaty te moga służyć za przykład zmian słabszym jednostkom. W grupie powiatów można także było wyróżnić takie, które z różnych przyczyn zanotowały regres w swoim rozwoju (powiat augustowski i hajnowski). Wykazały to obie zastosowane metody budowania rankingów.

Przeprowadzone badanie można traktować jako jedną z propozycji analizy w ramach literatury przedmiotu. Otrzymane wyniki są pewnym kompromisem pomiędzy próbą uzyskania oceny zróżnicowania poziomu powiatów ze względu na rozwój społecznogospodarczy a słabością niektórych zmiennych diagnostycznych, jak również wyborem metod.

\section{Literatura}

Grosse T. G. 2002 Przeglad koncepcii teoretycznych rozwoju regionalnego, „Studia Regionalne i Lokalne", nr 1(8).

Hellwig Z. 1968 Zastosowanie metody taksonomicznej do typologicznego podziatu krajón ze wagledu na poziom ich rozwoju i struktury mykwalifikowanych kadr, „Przegląd Statystyczny", nr 4.

Hwang C. L., Yoon K. 1981 Multiple Attribute Decision Making: Methods and Applications, Springer-Verlag, New York.

Jaffee D. 1998 Levels of socio-economic development theory, Praeger Westport, Connecticut London.

Kendall M.G. 1938 A new measure of rank correlation, „Biometrika”, No. 30.

Kubiczek A. 2014 Jak mierzyý dziś rozinój spoteczno-gospodarçy krajów?, „Nierówności społeczne a wzrost gospodarczy", nr 38 (2). 
Malina A. 2004 Wielowymiarowa analiza przestrzennego zróżnicowania struktury gospodarki Polski wedtug wojewódz̨tw, Akademia Ekonomiczna w Krakowie, Kraków.

Młodak A. 2006 Analiza taksonomiczna w statystyce regionalnej, Wydawnictwo Difin, Warszawa.

Panek T. 2009 Statystyczne metody wielowymiarowej analizy porównawczej, SGH w Warszawie, Warszawa.

Piontek B. 2010 Wspótczesne uwarunkowania rozwoju społeczno-gospodarczego (ujęie syntetyczne), „Problemy ekorozwoju”, vol. 5, no. 2.

Roszkowska E. 2009 Application the TOPSIS Methods for Ordering Offers in Buyer-Seller Transaction, „Optimum. Studia Ekonomiczne”, nr 3(43).

Roszkowska E., Karwowska R. 2014 Wielowymiarowa analiza poziomu zrównoważonego rozwoju województw Polski w 2010, „Economics and Management”, nr 1.

Roszkowska E., Misiewicz E.I., Karwowska R. 2014 Analiza poziomu zrównoważonego rozwoju województw Polski w 2010 roku, ,Ekonomia i Środowisko”, nr 2 (49).

Roszkowska E., Piotrowska E. 2011 Analiza zróżnicowania województw Polski w aspekcie ksztaltowania sie gospodarki opartej na wiedzy, [w:] W kierunku zrównoważonej gospodarki opartej na wiedzy w Polsce, P. Sochaczewski (red.), Wyższa Szkoła Ekonomiczna, Białystok.

Szirmai A. 2015 Socio-Economic development, Cambridge University Press, Cambridge.

UNDP 1990 Human Development Raport, Oxford University Press, Oxford.

UNDP 2012 Krajowy Raport o Rozwoju Społecznym. Polska 2012. Rozwój regionalny i lokalny, Biuro Projektowe UNDP w Polsce, Warszawa.

Warzecka K. 2013 Rozwój społeczno-gospodarczy polskich regionów a procesy migracji, „Studia Ekonomiczne", Uniwersytet Ekonomiczny w Katowicach, nr 142.

Wskaźniki zrównoważonego rozpoju Polski 2011, Główny Urząd Statystyczny, Katowice.

Wysocki F. 2010 Metody taksonomiczne w rozpoznawaniu typów ekonomicznych rolnictwa i obszarów wiejskich, Wydawnictwo Uniwersytetu Poznańskiego, Poznań.

Ziemiańczyk U. 2010 Ocena poziomu rozwoju społeczno-gospodarczego gmin wiejskich i miejskowiejskich w województwie małopolskim, PAN, Oddział w Krakowie, 14. 